\title{
Sociobiology
}

RESEARCH ARTICLE - TERMITES

\section{Landscape Factors Associated with Subterranean Termite (Isoptera: Rhinotermitidae) Treatments and Colony Structure in Residential Subdivisions}

\author{
PS BOTCH ${ }^{1,2}$, RM HOUSEMAN ${ }^{1}$ \\ 1 - Division of Plant Sciences, University of Missouri, Columbia, MO, USA \\ 2 - Department of Entomology, Michigan State University, East Lansing, MI, USA
}

\section{Article History}

\section{Edited by}

Paulo Cristaldo, UFS, Brazil

Received

27 June 2017

Initial acceptance

Final acceptance

Publication date

\section{August 2017}

20 September 2017

30 March 2018

\section{Keywords}

Colonization, termiticide, landscape ecology, microsatellites, Reticulitermes.

\section{Corresponding author \\ Paul Steven Botch \\ Department of Entomology \\ Michigan State University \\ 288 Farm Lane, Room 46 \\ East Lansing, MI 48824, USA. \\ E-Mail: botchpau@msu.edu}

\begin{abstract}
Subterranean termites (Isoptera: Reticulitermes) are common structural pests, but it is not well known how landscape factors are associated with urban colonization. This study examined patterns of subterranean termite colonization in 13 midMissouri residential subdivisions. Ten- and 20 -year-old homes built on historically agricultural and forested landscapes were inspected for treatment by termiticide application or bait stations. Contemporary and historical aerial imagery was analyzed using GIS software, and patterns of colonization were compared among subdivisions. The genetic structure of termite colonies collected in undeveloped landscapes and residential subdivisions was compared using microsatellite DNA. Twenty-year-old subdivisions had significantly higher treatment proportions than 10-year-old subdivisions. At year 10, historically forested subdivisions had a higher treatment proportion than historically agricultural subdivisions. By year 20 , there was no significant difference in treatment proportion between historical landscape types, indicating that subdivisions built on agricultural landscapes eventually catch up to subdivisions built on forest landscapes. Although there was not strong statistical support, treated homes in historically agricultural subdivisions tended to be close to forest patches, but there was less of an association in historically forested subdivisions. Colonies in undeveloped landscapes were more inbred compared to colonies in residential subdivisions, indicating that colonies sampled in subdivisions had fewer secondary reproductives and were potentially younger than those sampled in undeveloped landscapes. This study provides some correlative support for the role of dispersing alates as urban colonizers because treatments were often located at relatively long distances from undisturbed forest patches in historically agricultural subdivisions.
\end{abstract}

\section{Introduction}

Urban development alters natural processes including hydrologic regimes, soil chemistry and fertility, overall plant distribution, and fragmentation of the landscape (McDonnell \& Pickett, 1990; Turner et al., 2001). Animal and plant populations may respond to these changes by expanding or declining in numbers, migrating, or becoming extirpated from altered landscapes (Lomolino et al., 2006). Arthropod populations in urban landscapes are potentially relicts from pre-urban landscapes but may also colonize via dispersal from external habitats or anthropogenic introductions (Sattler et al., 2011). Despite their abundance in urban landscapes, little research has focused on the response of many arthropod groups to urban development (McIntyre, 2000).

Subterranean termites (Isoptera: Reticulitermes) occur in a variety of habitat types, including undisturbed forests and urban landscapes (Weesner, 1965). In forests, termites are beneficial because they break down woody debris, which contributes to nutrient cycling and soil fertility (Waller \& LaFage, 
1987). However, termites are economically destructive pests in urban landscapes when they feed on structural wood. Repair and prevention costs associated with termite structural infestations have been estimated to reach $\$ 40$ billion per year worldwide (Rust \& Su, 2012). Despite their economic importance, it is not well known how termite populations respond to urban development or what factors may be associated with subsequent urban colonization.

Subterranean termite activity occurs almost exclusively underground. A branching network of tunnels connects subterranean nests with cellulose food resources on the soil surface, where most of the foraging activity tends to concentrate (Traniello \& Leuthold, 2000). Because subterranean termite life history is inherently connected to soil conditions, it is likely that soil disturbances accompanying urban development would have negative effects on subterranean colonies. During urban development, topsoil is highly altered by removing or filling in areas to prepare landscapes for construction (Capachi, 1978; Petschek, 2008). Soil alterations may also remove subterranean termite populations locally from areas of disturbance. For example, soil alterations were reported to physically remove the majority of soil-dwelling ant species in lots prior to home construction (Buczkowski \& Richmond, 2012). Reticulitermes spp. in Missouri are also likely removed locally when soil is heavily disturbed by construction processes (Botch \& Houseman, 2016).

If subterranean termites are locally removed by subdivision construction processes, infested homes are presumably colonized from dispersing source populations outside of the disturbed area, or by accidental human introductions. Subterranean termites can disperse to new areas by tunneling underground or through swarming by reproductive adults (alates). Reticulitermes spp. have been estimated to tunnel at generally short linear distances $(<10$ $\mathrm{m})$ based on population analyses using molecular techniques (Vargo \& Husseneder, 2009). It is not known how far alates can disperse from parent nests, but termites are recognized as poor fliers with trajectories often influenced by wind (Weesner, 1965). However, thousands of individuals are produced during swarming season, some of which could be capable of establishing incipient colonies at long distances from the parent colonies.

The goals of this study were to examine patterns of colonization in residential subdivisions of different ages and historical vegetation. The first objective was to identify landscape patterns of colonization over time by inspecting homes for evidence of subterranean termite treatment. In Missouri, subterranean termite management usually consists of either a post-construction application of soil termiticide, or use of underground bait stations. Post-construction applications of soil termiticide involve trenching into the ground around the outside perimeter of the home and injecting the chemical into the soil to form a continuous treated zone around the house (Su \& Scheffrahn, 1990; Su \& Scheffrahn, 1998;
Houseman, 2007). Concrete slabs adjoining the building, such as porches or driveways, require that holes are drilled through the concrete to treat the soil beneath. The injection holes are later filled with mortar, leaving distinct, evenlyspaced markings in the concrete. Unlike southern states with higher termite pressure, there are no laws in Missouri requiring homes be treated for subterranean termites prior to or during construction. Consequently, most homes are not pretreated. According to the Suggested Guidelines for Completing the Wood Destroying Insect Inspection Report - NPMA33, termite control treatment should only be recommended by an inspector when there are either live termites in or on the structure, or there is evidence of infestation in or on a structure (Houseman, 2007). Due to these guidelines, and because subterranean termite treatments are expensive, it is likely that very few post-construction treatments are the result of preventative measures, and therefore most treated homes in Missouri are due to previous termite activity. We hypothesized that treatments would be correlated with historical and contemporary landscape features such as forest patches from which termites may disperse, and subdivision age, which can predict treatment frequency (Houseman 2010). Understanding how historic and contemporary landscape factors influence subterranean termite colonization could improve the ability to predict the risk of homes to infestation and lead to better management strategies.

The second objective was to determine the potential effects subdivision development has on subterranean termites by examining colony structure. Direct observation of subterranean colonization and breeding is inherently challenging due to their cryptic nature; however molecular tools can be used to infer genetic relationships of colonies (Vargo \& Husseneder, 2009). Our goal was to use these techniques to evaluate the breeding structure of termites in undisturbed forests and subdivisions to compare relative colony maturities. The offspring of colonies headed by a monogamous pair of primary reproductive (king and queen) have genotypes conforming to Mendelian ratios and are termed simple families (Vargo, 2003b; Vargo \& Husseneder, 2009). Offspring are reproductively suppressed by a pheromone produced by the primary queen (Matsuura et al., 2010). When the pheromone is lacking or diminishes in the colony, due to either queen death or spatial isolation from the queen, worker termites may differentiate into neotenics in high numbers leading to increased colony growth (Thorne et al., 1999). Because neotenics do not leave the nest, these colonies (termed extended families) experience generations of inbreeding and can be identified by genotype frequencies that deviate significantly from Mendelian ratios (Vargo, 2003b; Vargo \& Husseneder, 2009; Thorne et al., 1999). We hypothesized that undeveloped forest landscapes would contain a higher proportion of extended families and higher levels of inbreeding because these areas lack anthropogenic disturbances. Conversely, we expected residential subdivisions to contain a higher proportion of simple families and lower 
levels of inbreeding due to construction, termite management, or other anthropogenic disturbances.

\section{Methods}

Three undeveloped forest landscapes and thirteen subdivisions in Columbia, Missouri were used as study areas for this project. Residential subdivisions were chosen based on the following classifications: 1) 10-year-old subdivisions built on historically forested landscapes (3 subdivisions surveyed); 2) 10-year-old subdivisions built on historically agricultural landscapes (4 subdivisions surveyed); 3) 20-yearold subdivisions built on historically forested landscapes (3 subdivisions surveyed); or 4) 20-year-old subdivisions built on historically agricultural landscapes (3 subdivisions surveyed). Subdivisions were defined as historically forested or agricultural when over $60 \%$ of the area consisted of the corresponding land cover prior to construction. The landscapes were classified and verified using GIS and land use land cover (LULC) data and aerial photography from The Missouri Spatial Data Information Service (http://msdis.missouri. edu), The Center for Applied Research and Environmental Systems (http://www.cares.missouri.edu/), the Boone County Assessor's Office online parcel information viewer (http:// www.showmeboone.com/assessor/), and Google Earth. Overall landscape composition was digitized and quantified using ArcMap v.10.0. Remnant forest patches were also delineated by comparing historical imagery of forested areas prior to subdivision construction with contemporary forest patches. The historical land cover for each home was defined at two spatial scales: 1) at the overall subdivision level, and 2) for individual home lots (Fig 1) using GIS datasets. At the overall subdivision level, the historical landscape was classified as forest or agricultural based on the dominant landscape type prior to construction of the subdivision. Historical land cover for individual lots was classified after aerial photography was georeferenced and digitized. Home ages for each property were determined using the Boone County Assessor's Office online parcel information viewer. Homes that were eight to twelve years-old were grouped into the 10-year age class, and homes that were 18 to 22 years old were grouped into the 20 year age class.

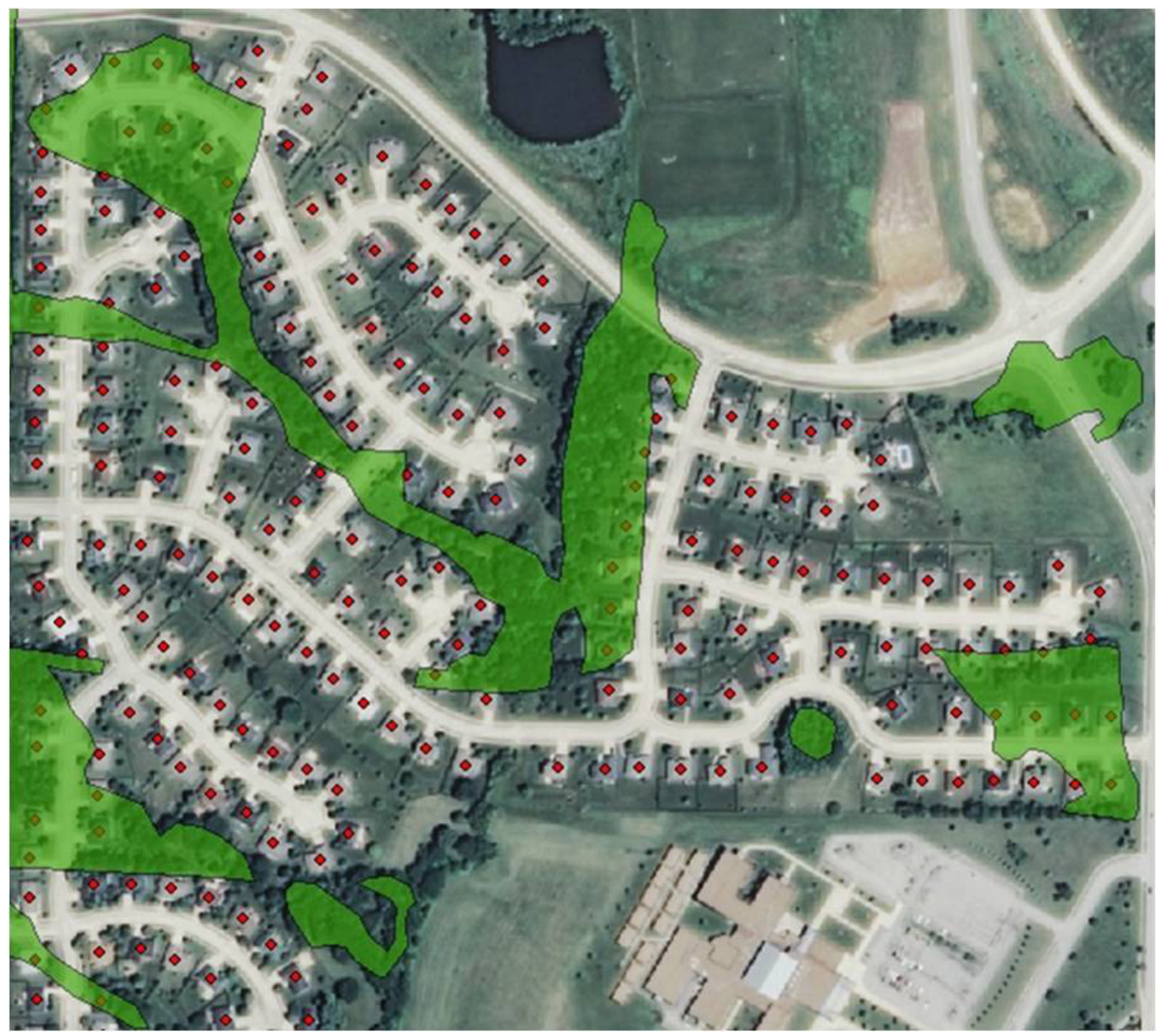

Fig 1. Historical landscapes were classified at two spatial scales: 1) for the overall subdivision and 2) for individual lots. The dominant historical landscape-type for this 10-year-old subdivision was agricultural. Woodlot patches that existed prior to construction were digitized (shaded in green) from georeferenced historical aerial imagery to determine the pre-construction vegetation for individual home lots. Thus, although the overwhelming majority of homes were built on agricultural landscape, some homes were built on woodlot patches, which were cleared before construction. Uncleared remnant patches of woodlot may serve as refuges for relict subterranean termite populations and sources of future colonization. 
Individual homes in each subdivision were inspected for subterranean termite treatment. Homes were considered treated when termiticide treatment marks were identified in concrete slabs adjoining homes, including driveways and porches, or if termite bait stations were observed in yards or mulch beds. Treatment proportions were compared between homes of different ages and historical landscape types using the GLIMMIX procedure (Proc GLIMMIX, SAS Institute Inc., 2011) at both spatial scales. The overall proportion of woodlot area for each subdivision-type was compared using a t-test. Patch isolation between woodlots was calculated using the Euclidean Nearest Neighbor (ENN) statistic in FRAGSTATS 3.3 (McGarigal et al., 2002). Distances (m) between homes and their nearest forest patches were calculated in ArcMap and compared between treated and untreated homes in all subdivisions. Significant differences were assessed using the Kruskal-Wallis one-way Analysis of Variance (Proc Npar1way, SAS Institute Inc., 2011).

Subterranean termites were sampled from undeveloped forest landscapes and untreated homes in 10- and 20-year-old previously forested subdivisions. Sampling was conducted using monitor units consisting of two adjacent 9" pine stakes with a steel nail driven into the top of the stakes so they could be found with a metal detector. The monitoring units were placed into holes excavated by an auger and then covered with soil. At each home, monitors were buried at: 1) the front of the property near the sidewalk; 2) near the front porch; 3 ) near the back porch; and 4) toward the rear property line. In forested landscapes, grids containing $25 \mathrm{~m} \times 50 \mathrm{~m}$ plots were overlaid onto geo-referenced aerial landscape photography using ArcMap 10.0, to simulate subdivision plats. Monitoring units were buried 12 meters apart in linear transects of randomly selected plats. Monitors were examined for termites over two consecutive years. Termites were also sampled from logs, landscaping timbers, and other woody debris found within individual lots. Sampled termites were preserved in $90-100 \%$ ethanol and stored in a $-25^{\circ} \mathrm{C}$ freezer.

PCR-RFLP methods developed by Szalanski et al. (2003) and described in Botch and Houseman (2016) were used to identify species of subterranean termites collected. Only colonies identified as $R$. flavipes were analyzed in this study. Fourteen microsatellite loci were screened for polymorphisms among termite populations by amplifying DNA from 10 workers collected at 10 different locations. The reaction mixture consisted of $1.0 \mu 1$ template DNA, $2.5 \mu 1$ of $5 \mathrm{x}$ reaction buffer, $2.0 \mu \mathrm{l} \mathrm{MgCl}_{2}, 0.5 \mu 110 \mathrm{mM}$ dNTP mix, $1.0 \mu \mathrm{BSA}, 1.0 \mu \mathrm{l}$ each of forward and reverse primer, $0.2 \mu \mathrm{l}$ GoTaq Flexi DNA polymerase, and $15.8 \mu 1 \mathrm{ddH}_{2} 0$ to a final volume of $25.0 \mu \mathrm{l}$. The PCR reactions were conducted on an Eppendorf Mastercycler Pro using following program: initial denaturation step at $94{ }^{\circ} \mathrm{C}(30 \mathrm{~s})$, followed by 30 cycles at 94 ${ }^{\circ} \mathrm{C}(30 \mathrm{~s}), 55-57^{\circ} \mathrm{C}(30 \mathrm{~s}), 72^{\circ} \mathrm{C}(30 \mathrm{~s})$, with a final extension step at $72{ }^{\circ} \mathrm{C}(5 \mathrm{~min})$. The PCR product was separated by $6 \%$ agarose gel electrophoresis, stained with ethidium bromide, and photographed using a Syngene G:Box imaging system. Microsatellite loci were considered polymorphic when gels produced bands of different sizes, indicating allelic variation among populations.

From these tests, eight loci $R F 1-3, R f 11-1, R f 15-2$, and Rf21-1 (Vargo, 2000), and Rs 16, Rs43, Rs68, and Rs85 (Dronnet et al., 2004) were considered polymorphic and appropriate for analyzing populations. Ten $R$. flavipes colonies were randomly chosen from undeveloped forested landscapes, 10-year-old subdivisions, and 20-year-old subdivisions for a total of 30 analyzed colonies. DNA was isolated from the heads of 20 worker termites from most colonies (in two colonies, only 13 or 11 workers were available). Based on DNA fragment length (bp) and optimal annealing temperatures, the loci were grouped into two multiplex reactions using the software program Multiplex Manager(C) $\mathrm{v}$ 1.2. Loci in each multiplex reaction were assigned one of four fluorescent dyes: 6-Fam (blue), VIC (green), NED (yellow), or PET (red). The first multiplex contained loci Rf21-1 (6-Fam), Rf15-2 (VIC), Rs43 (NED), and Rfl-3(PET), and the second multiplex contained loci Rf11-1 (6-Fam), $R s 85$ (VIC), Rs 16 (NED), and $R s 68$ (PET). Each termite was genotyped by amplifying DNA in both multiplex reactions using ABI Platinum ${ }^{\circledR}$ Multiplex PCR Master Mix according to the manufacturer's recommendations. Individual reactions contained $1.00 \mu 1$ template DNA, $3.90 \mu 1$ Master Mix, $0.93 \mu 1$ GC Enhancer, $0.89 \mu 1$ diluted primer mix, and $1.28 \mu \mathrm{ldd}_{2} 0$ to a final volume of $8.0 \mu$ l. The PCR reactions were conducted on an Eppendorf Mastercycler Pro, using following program: initial denaturation step at $95{ }^{\circ} \mathrm{C}(2 \mathrm{~min})$, followed by 28 cycles at $95{ }^{\circ} \mathrm{C}(30 \mathrm{~s}), 57{ }^{\circ} \mathrm{C}(1: 30 \mathrm{~min}), 72{ }^{\circ} \mathrm{C}(1 \mathrm{~min})$, with a final extension step at $60{ }^{\circ} \mathrm{C}(30 \mathrm{~min})$. The amplified product was diluted to $1: 100$ and sent to the University of Missouri's DNA Core facility for fragment analysis using the ABI 3730xl DNA Analyzer. The software program Peak Scanner $^{\mathrm{TM}}$ v 1.0 (Thermo Fisher Scientific, 2012) was used to score allele sizes of microsatellite loci for each individual termite at all loci. The genotype at each locus was determined to be homozygous if only one allele size was detected and heterozygous if two allele sizes were detected.

The genotype frequency within each colony was used to classify $R$. flavipes colonies as simple, extended, or mixed families. Simple families contain genotypes consistent with a colony headed by a monogamous pair of reproductives. These colonies contain four or fewer allelic combinations at each locus, or genotype frequencies that do not significantly deviate from expected frequencies based on a G-test combined over all loci (Vargo, 2003b). A G-value for each locus was assessed using the following equation: $\mathrm{G}=2 \sum[\mathrm{O} * \ln (\mathrm{O} / \mathrm{E})]$, where $\mathrm{O}=$ the observed number for a genotype and $\mathrm{E}=$ the expected number for a genotype (Sokal \& Rohlf, 2012). The observed and expected values for each genotype were calculated using the program Fstat v 2.9.3.2 (Goudet, 2002). Because the G-test is additive, G-values are added across all loci for each colony 
to determine an overall G-value. The alpha level 0.05 was adjusted with a Bonferroni correction based on the number of loci used in the G-test. Extended families contain either more than four genotypes at a given locus, or genotype frequencies that significantly deviate from expected frequencies based on a G-test (Vargo, 2003b).

Unlike simple or extended families, mixed families can be identified by the presence of five or more alleles at one or more loci. Five or more alleles at a given locus is not possible among colony members descended from a single reproductive pair, and therefore, mixed families are formed by two or more unrelated reproductive lines, possibly as a result of colony fusion (Vargo, 2003b, DeHeer \& Vargo, 2004).

Inbreeding and relatedness was further examined by using $F$-statistics (Weir \& Cockerham, 1984) to infer breeding structure within colonies (Thorne et al., 1999). $F$-statistics calculate genetic differentiation at three levels: 1) $F_{I S}$, which is the level of inbreeding of individuals relative to the subpopulation; 2) $F_{S T}$, which is the level of inbreeding among subpopulations; and 3) $F_{I T}$, which is the overall inbreeding coefficient of individuals relative to the total population (Freeland, 2005). A unique $F$-statistic notation is given to social insects, whereas: 1) $F_{I C}$ is the level of inbreeding of individuals relative to the colony; 2) $F_{C T}$ is the level of inbreeding among colonies; and 3) $F_{I T}$ is the level of inbreeding of individuals relative to the total population (Thorne et al., 1999). $F_{I C}$ is particularly useful in determining breeding structure in subterranean termite colonies because it is expected to increase in value relative to the number of secondary reproductives mating within a colony (Thorne et al., 1999; Bulmer et al., 2001; Vargo, 2003b). Strongly negative values are indicative of low levels of inbreeding associated with simple families headed by monogamous reproductives. $F_{I C}$ values that are less negative, approach zero, or are positive are associated with extended families containing inbreeding by many secondary reproductives (Thorne et al., 1999; Bulmer et al., 2001; Vargo, 2003b). All $F$-statistics and confidence intervals (95\%) were calculated using Fstat.

\section{Results}

A total of 1,728 homes were surveyed and 913 homes fell within the 10- and 20-year-old age classes. Of these, 109 homes had been previously treated for subterranean termites (Table 1). Mean treatment proportions for subdivisions according to overall landscape type were: 10-year-old historically agricultural $2.64 \%, \quad \mathrm{STD}=1.84 ; 10$-yearold historically forested $7.66 \%$, STD $=3.19 ; 20$-year-old historically agricultural $19.93 \%$, STD $=4.45$; and 20-yearold forested $23.40 \%$, STD $=7.20$. Treatment proportion was significantly lower in 10-year-old subdivisions than 20 -year-old subdivisions for both historically agricultural ( $\alpha$ $\leq 0.05 ; \mathrm{p}=0.0001)$ and historically forested $(\alpha \leq 0.05 ; \mathrm{p}=$ 0.0069 ) subdivisions (Fig 2 ). Ten-year-old historically forested subdivisions had a significantly higher treatment proportion than 10-year-old historically agricultural subdivisions $(\alpha \leq 0.05$; $\mathrm{p}=0.0246$ ). There was no significant difference in treatment proportion between historically forested and agricultural subdivisions at year $20(\alpha \leq 0.05 ; \mathrm{p}=0.5616)$, however (Fig 2).

Mean treatment proportions based on the historical vegetation at individual home lots were: 10-year-old historically agricultural lots $4.09 \%$, STD $=6.09 ; 10$-year-

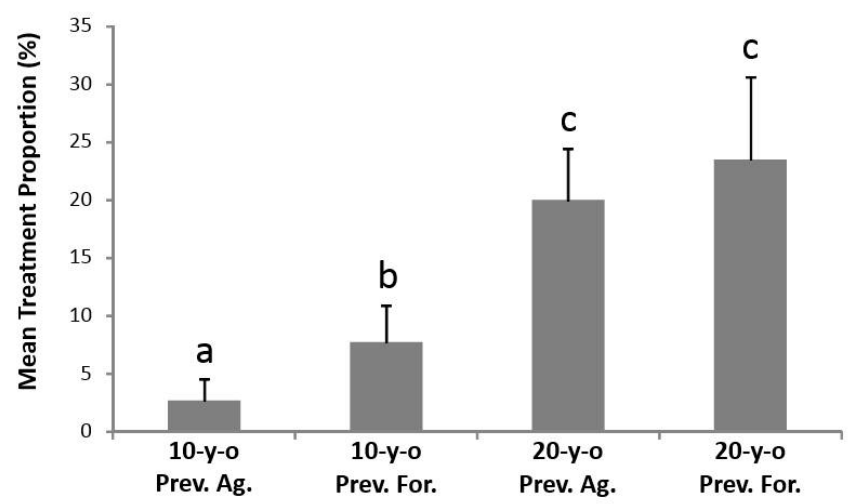

Fig 2. Mean proportions and standard deviations for subterranean termite (Isoptera: Reticulitermes) treatments in historically agricultural 10-year-old subdivisions, historically forested 10-yearold subdivisions, historically agricultural 20-year-old subdivisions, and historically forested 20-year-old subdivisions. There was a significantly higher treatment proportion in 20-year-old subdivisions than 10-year-old subdivisions that were historically agricultural $(\alpha \leq$ $0.05 ; \mathrm{p}=0.0001)$ and forested $(\alpha \leq 0.05 ; \mathrm{p}=0.0069)$. Historically forested 10 -year-old subdivisions had a significantly higher treatment proportion than historically agricultural 10-year-old subdivisions $(\alpha \leq 0.05 ; \mathrm{p}=0.0246$ ); however historically forested 20 -year-old subdivisions did not have a significantly higher treatment proportion than historically agricultural subdivisions $(\alpha \leq 0.05 ; \mathrm{p}=0.5616)$.

Table 1. Summary of subdivision homes and subterranean termite (Isoptera: Reticulitermes) treatment totals in historically agricultural 10-year-old subdivisions, historically forested 10-year-old subdivisions, historically agricultural 20-year-old subdivisions, and historically forested 20-year-old subdivisions in Columbia, MO.

\begin{tabular}{rcccc}
\hline Subdivision type & No. Subdivisions & $\begin{array}{c}\text { Total } \\
\text { homes }\end{array}$ & $\begin{array}{c}\text { Total treated } \\
\text { homes }\end{array}$ & Treated homes in 5-yr window \\
\hline 10 YO Subdivision - Previous Forest & 3 & 344 & 22 & 16 \\
10 YO Subdivision - Previously Agricultural & 4 & 619 & 17 & 11 \\
20 YO Subdivision - Previously Forest & 3 & 408 & 88 & 22 \\
20 YO Subdivision - Previously Agricultural & 3 & 357 & 68 & 60 \\
Total & $\mathbf{1 3}$ & $\mathbf{1 7 2 8}$ & $\mathbf{1 9 5}$ & $\mathbf{1 0 9}$ \\
\hline
\end{tabular}


old historically forested lots $4.63 \%, \mathrm{STD}=3.36 ; 20$-yearold historically agricultural lots $19.13 \%, \mathrm{STD}=9.36$; and 20 -year-old historically forested lots $23.03 \%$, STD $=6.44$. Treatment proportions were significantly higher for 20-yearold homes than 10-year-old homes for historically agricultural lots $(\alpha \leq 0.05 ; \mathrm{p}=0.0005)$ and forested lots $(\alpha \leq 0.05 ; \mathrm{p}=$ $0.0007)$. There was no significant difference in treatment proportions between homes built on historically agricultural or historically forested lots at either $10(\alpha \leq 0.05 ; \mathrm{p}=0.7269)$ or 20 years $(\alpha \leq 0.05 ; p=0.4226)$ (Fig 3$)$.

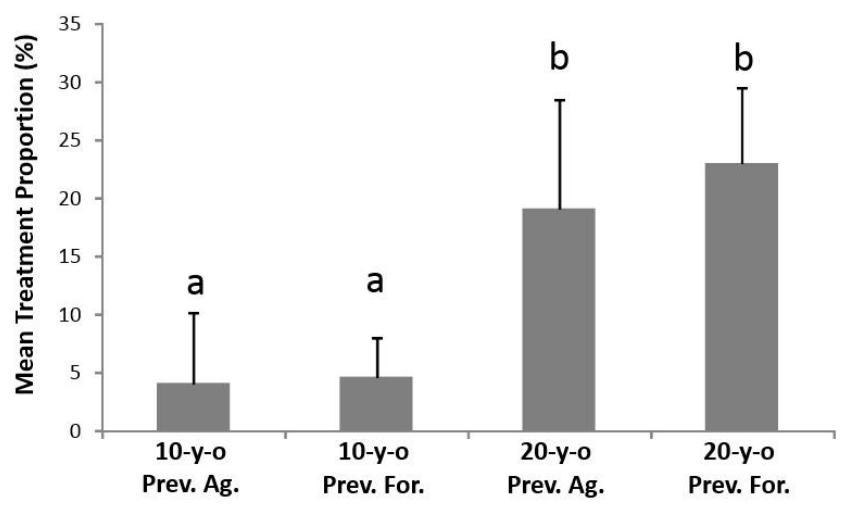

Fig 3. Mean proportions and standard deviations for subterranean termite (Isoptera: Reticulitermes) treatments for individual home lots that were historically agricultural or historically forested at years 10 and 20. Treatment proportions were significantly different between 10 -year-old homes and 20-year-old homes built on agricultural land $(\alpha \leq 0.05 ; p=0.0005)$ and forested land $(\alpha \leq 0.05 ; p=0.0007)$, but there were no significant differences between treatment proportions when historical landscape conditions of individual home lots were compared at 10 years $(\alpha \leq 0.05 ; p=0.7269)$ or 20 years $(\alpha \leq 0.05$; $\mathrm{p}=0.4226)$.

In historically agricultural subdivisions, treated homes had a shorter mean distance to contemporary forest patches $(52.26 \mathrm{~m})$ than untreated homes $(66.71 \mathrm{~m})$ at year ten (Table 2). Twenty-year-old historically agricultural subdivisions showed a similar trend where treated homes had a significantly shorter $(\alpha \leq 0.05)$ mean distance $(24.45 \mathrm{~m})$ to contemporary forest patches than untreated homes $(32.18 \mathrm{~m})$. Ten-year-old historically forested subdivisions showed the opposite trend where treated homes had a greater distance to contemporary forest patches $(55.54 \mathrm{~m})$ than untreated homes (39.68).
In 20-year-old historically forested subdivisions, treated homes had a shorter mean distance to contemporary forest patches $(12.96 \mathrm{~m})$ than untreated homes $(15.45 \mathrm{~m})$ (Table 2).

Proportions of forested area within these subdivisions were previously reported in Botch \& Houseman (2016) and were also used to evaluate how they were associated with treatment proportion for this study. Mean proportion of contemporary forest area for subdivisions was $5.25 \%$ for 10 -year-old historically agricultural, $29.30 \%$ for 10 -yearold historically forest, $17.16 \%$ for 20 -year-old historically agricultural, and $43.29 \%$ for 20 -year-old historically forest (Fig 4). At year 10, historically forest subdivisions had significantly more contemporary forest area than historically agricultural subdivisions ( $\mathrm{p}=0.0177 ; \alpha \leq 0.05$; t-test). However, at year 20, there was no significant difference in contemporary forest area between historically agricultural and historically forest subdivisions ( $\mathrm{p}=0.0701 ; \alpha \leq 0.05$; t-test). Forest patches in 10 -year-old historically agricultural subdivisions were more isolated than in other subdivision types and had the highest patchiness value $(\mathrm{ENN}=4617.8)$, compared to 10-year-old historically forested subdivisions $(E N N=2575.2)$, 20-year-old historically agricultural subdivisions $(\mathrm{ENN}=2225.2)$, or 20-year-old historically forested subdivisions $(\mathrm{ENN}=2681.7)$.

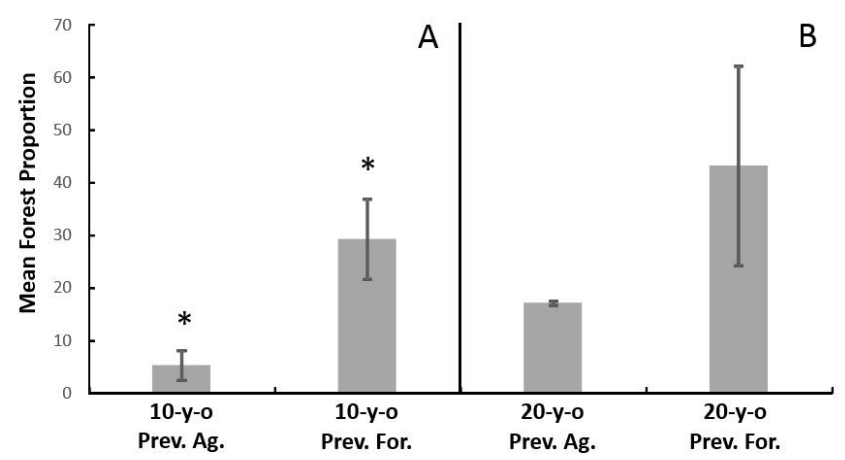

Fig 4. Mean proportion of contemporary forest area in A) 10-yearold historically agricultural and forested subdivisions, and B) 20-year-old historically agricultural and forested subdivisions in Columbia, MO. There was a significant difference in forest area between subdivisions built on different historical landscapes at year 10 ( $\mathrm{p}=0.0177 ; \alpha \leq 0.05$; t-test), but not at year 20 ( $\mathrm{p}=0.0701$; $\alpha \leq 0.05$; t-test). Significant differences are indicated by an asterisk above standard deviation bars.

Table 2. Mean distance $(\mathrm{m})$ to nearest forest patch for untreated homes $(\mathrm{Nu})$ and treated homes $(\mathrm{Nt})$ in historically agricultural 10 -year-old subdivisions, historically forested 10-year-old subdivisions, historically agricultural 20 -year-old subdivisions, and historically forested 20-year-old subdivisions in Columbia, MO.

\begin{tabular}{|c|c|c|c|c|c|c|c|}
\hline \multirow[b]{2}{*}{ Subdivision } & \multirow[b]{2}{*}{$\mathrm{Nn}$} & \multirow[b]{2}{*}{$\mathrm{Nt}$} & \multicolumn{2}{|l|}{ Non-treated } & \multicolumn{2}{|l|}{ Treated } & \multirow[b]{2}{*}{$\mathrm{p}$} \\
\hline & & & Mean Distance to Forest & Stdev & Mean Distance to Forest & Stdev & \\
\hline $10 \mathrm{YO} \mathrm{Ag}$ & $\mathrm{n}=406$ & $\mathrm{n}=11$ & 66.71 & 42.04 & 52.26 & 36.55 & 0.23 \\
\hline 10YO For & $\mathrm{n}=192$ & $\mathrm{n}=16$ & 39.68 & 42.17 & 55.54 & 49.18 & 0.30 \\
\hline $20 \mathrm{YO} \mathrm{Ag}$ & $\mathrm{n}=241$ & $\mathrm{n}=60$ & 32.18 & 23.90 & 24.45 & 21.22 & 0.01 \\
\hline 20YO For & $\mathrm{n}=74$ & $\mathrm{n}=22$ & 15.45 & 9.23 & 12.96 & 3.65 & 0.69 \\
\hline
\end{tabular}


Six of the eight microsatellite loci used in this study were determined to be polymorphic among colonies that were sampled. The overall number of detected alleles ranged between 2 and 14 at loci $R f 21-1, R f 1-3, R f 11-1, R s 85, R s 16$, and $R s 68$ (Table 3). Loci $R f 15-2$ and $R s 43$ showed no variation among colonies, and therefore were not used to interpret breeding structure. No colonies contained more than four alleles at a given locus, and therefore there was no evidence of mixed families. Colonies that deviated from Mendelian rules of inheritance and from expected genotype frequencies using a G-test were determined to be extended families. This included 6 of 10 colonies from undeveloped forested areas, 5 of 10 colonies from 10-year-old subdivisions, and 5 of 10 from 20-year-old subdivisions (Table 4).

The overall $F_{C T}$ value was 0.345 (Table 4), and therefore there was distinct genetic variation between colonies. The $F_{I T}$, or overall inbreeding coefficient of individuals relative to the entire population, was highest in undeveloped forested areas $\left(F_{I T}=0.302,95 \% \mathrm{CI}=0.160\right.$ 0.451 , Table 4$)$. This value is over twice as high as 10 -yearold subdivisions $\left(F_{I T}=0.125,95 \% \mathrm{CI}=0.054-0.179\right)$ or 20 -year-old subdivisions $\left(F_{I T}=0.116,95 \% \mathrm{CI}=-0.083\right.$ 0.199 ), though not significantly higher due to overlapping CI's. $F_{I C}$ values are expected to be strongly negative for simple families and approach zero in extended families due to an increase in secondary reproductives within the colony. The overall $F_{I C}$ value for undeveloped forests is $-0.081(95 \%$ $\mathrm{CI}=-0.149$ to -0.023$)$. Partitioning this value among family types gives values of $-0.126(95 \% \mathrm{CI}=-0.324$ to -0.002$)$ for simple families and $-0.061(95 \% \mathrm{CI}=-0.149$ to -0.023$)$ for extended families. The value for extended families is closer to zero, which is expected. $F_{I C}$ values for simple and extended families deviated from these expectations, however. In 10-year-old subdivisions, simple families had an $F_{I C}$ value of $-0.177(95 \% \mathrm{CI}=-0.251$ to -0.087$)$ and extended families had an $F_{I C}$ value of $-0.308(95 \% \mathrm{CI}=-0.382$ to -0.213$)$. In 20-year-old subdivisions, simple families had an $F_{I C}$ value of $-0.265(95 \% \mathrm{CI}=-0.304$ to -0.218$)$ and extended families had an $F_{I C}$ value of $-0.411(95 \% \mathrm{CI}=-0.524$ to -0.324$)$ (Table 4).

\section{Discussion}

We found that subterranean termite treatment proportion was positively associated with subdivision age, as well as historical landscape-type for newer subdivisions. Treatment proportion was significantly higher in 20-year-old subdivisions than in 10-year-old subdivisions, indicating that termite infestations become more common as homes age. Treatment proportion was also significantly higher in 10-yearold subdivisions built on historically forested landscapes than in 10-year-old subdivisions built on historically agricultural landscapes. There was no difference between treatment proportions in 20-year-old subdivisions built on historically forested or agricultural landscapes. Treatment proportion for
Table 3. Overall allele frequencies for each locus in a microsatellite analysis of eight loci. The size (bp) and frequency of alleles at each locus are given. All_W is the estimated allele frequency weighted by sample size, while All_UW is the unweighted allele frequency among colonies.

\begin{tabular}{|c|c|c|c|}
\hline & Allele size & All_W & All_UW \\
\hline \multirow[t]{14}{*}{$R f 21-1$} & 210 & 0.209 & 0.214 \\
\hline & 213 & 0.293 & 0.291 \\
\hline & 216 & 0.019 & 0.019 \\
\hline & 225 & 0.044 & 0.041 \\
\hline & 229 & 0.128 & 0.122 \\
\hline & 231 & 0.011 & 0.01 \\
\hline & 237 & 0.016 & 0.016 \\
\hline & 240 & 0.004 & 0.004 \\
\hline & 244 & 0.012 & 0.011 \\
\hline & 247 & 0.12 & 0.126 \\
\hline & 250 & 0.015 & 0.014 \\
\hline & 256 & 0.105 & 0.103 \\
\hline & 259 & 0.013 & 0.018 \\
\hline & 286 & 0.012 & 0.011 \\
\hline \multirow[t]{4}{*}{$R f 1-3$} & 195 & 0.595 & 0.596 \\
\hline & 210 & 0.003 & 0.003 \\
\hline & 212 & 0.371 & 0.371 \\
\hline & 213 & 0.032 & 0.031 \\
\hline \multirow[t]{7}{*}{$R f 11-1$} & 221 & 0.007 & 0.007 \\
\hline & 222 & 0.028 & 0.03 \\
\hline & 223 & 0.015 & 0.014 \\
\hline & 226 & 0.022 & 0.022 \\
\hline & 230 & 0.372 & 0.361 \\
\hline & 232 & 0.295 & 0.306 \\
\hline & 235 & 0.262 & 0.259 \\
\hline \multirow[t]{2}{*}{$R s 85$} & 236 & 0.011 & 0.01 \\
\hline & 240 & 0.989 & 0.99 \\
\hline \multirow[t]{2}{*}{$R s 16$} & 286 & 0.904 & 0.902 \\
\hline & 288 & 0.096 & 0.098 \\
\hline \multirow[t]{3}{*}{$R s 68$} & 159 & 0.161 & 0.157 \\
\hline & 163 & 0.833 & 0.833 \\
\hline & 167 & 0.006 & 0.011 \\
\hline$R f 15-2$ & 213 & 1 & 1 \\
\hline$R s 43$ & 215 & 1 & 1 \\
\hline
\end{tabular}

20-year-old subdivisions built on either forests or agricultural landscapes was approximately $20 \%$. This supports the $20-20$ rule for treatment rates in central Missouri previously reported by Houseman (2010).Thus, historical landscape conditions appear to influence subterranean termite infestations in younger subdivisions, but the influence declines as subdivisions age. Treatment proportion in historically agricultural subdivisions 
Table 4. F-statistics and relatedness coefficients for Reticulitermes flavipes (Kollar) colonies in undeveloped forests, 10-yearold subdivisions, and 20-year-old subdivisions. $F_{I T}$ is the level of inbreeding of individuals relative to the total population. $F_{C T}$ is the level of inbreeding among colonies. $F_{I C}$ is the level of inbreeding of individuals relative to the colony. The relatedness $r$ is a measure of average relatedness of individuals within colonies relative to the entire population. 95\% confidence intervals (CI) are given in parentheses under each value. 95\% confidence intervals (CI) are given in parentheses under each value.

\begin{tabular}{|c|c|c|c|c|}
\hline & $F_{I T}$ & $F_{C T}$ & $F_{I C}$ & $r$ \\
\hline All colonies & 0.203 & 0.345 & -0.218 & 0.574 \\
\hline$(\mathrm{n}=30)$ & $(0.148-0.258)$ & $(0.307-0.371)$ & $(-0.26-0.155)$ & $(0.526-0.600)$ \\
\hline Undeveloped forest colonies & 0.302 & 0.354 & -0.081 & 0.544 \\
\hline$(\mathrm{n}=10)$ & $(0.160-0.451)$ & $(0.259-0.495)$ & $(-0.149-0.023)$ & $(0.444-0.684)$ \\
\hline Simple families & 0.374 & 0.444 & -0.126 & 0.646 \\
\hline$(n=4)$ & $(0.187-0.474)$ & $(0.368-0.512)$ & $(-0.324-0.002)$ & $(0.586-0.718)$ \\
\hline Extended families & 0.294 & 0.334 & -0.061 & 0.516 \\
\hline$(n=6)$ & $(0.148-0.470)$ & $(0.217-0.481)$ & $(-0.114-0.013)$ & $(0.378-0.659)$ \\
\hline 10-YO subdivision colonies & 0.125 & 0.299 & -0.248 & 0.531 \\
\hline$(\mathrm{n}=10)$ & $(0.054-0.179)$ & $(0.228-0.337)$ & $(-0.290-0.199)$ & $(0.432-0.582)$ \\
\hline Simple families & 0.28 & 0.388 & -0.177 & 0.607 \\
\hline$(\mathrm{n}=5)$ & $(0.093-0.476)$ & $(0.248-0.525)$ & $(-0.251-0.087)$ & $(0.453-0.713)$ \\
\hline Extended families & -0.006 & 0.231 & -0.308 & 0.465 \\
\hline$(\mathrm{n}=5)$ & $(-0.172-0.084)$ & $(0.133-0.277)$ & $(-0.382-0.213)$ & $(0.317-0.519)$ \\
\hline 20-YO subdivision colonies & 0.116 & 0.344 & -0.346 & 0.616 \\
\hline$(\mathrm{n}=10)$ & $(-0.083-0.199)$ & $(0.233-0.397)$ & $(-0.422-0.276)$ & $(0.502-0.666)$ \\
\hline Simple families & 0.28 & 0.431 & -0.265 & 0.674 \\
\hline$(n=5)$ & $(0.118-0.394)$ & $(0.312-0.522)$ & $(-0.304-0.218)$ & $(0.559-0.749)$ \\
\hline Extended families & -0.017 & 0.279 & -0.411 & 0.569 \\
\hline$(\mathrm{n}=5)$ & $(-0.296-0.117)$ & $(0.154-0.335)$ & $(-0.524-0.324)$ & $(0.437-0.603)$ \\
\hline
\end{tabular}

eventually catches up to treatments in historically forested subdivisions. Although the overall increase in treatment proportion in older subdivisions is likely to be due in part to degradation of homes over time, it may also be influenced by landscape composition. We found that remnant forest patches tended to increase in size and fill in around homes as historically agricultural subdivisions age. The increase in termite infestations by year 20 may also be influenced by increased available undeveloped habitat and woody debris, in addition to home age.

Remnant forest patches in subdivision landscapes that are not altered potentially contain relict termite colonies. Tenyear-old historically forested landscapes tended to have more remnant patches than 10-year-old historically agricultural landscapes, which had the fewest treatments and the least amount of forested area. This may explain why treatment proportions were significantly different between historical landscape types at year 10 . This also provides further evidence that the presence of forest cover may be related to infestation proportion (Houseman, 2010). Few studies have evaluated termite colonization following landscape perturbation. In Uganda forests, Okwakol (2000) reported that termite species richness was significantly reduced following clear-cutting, and species richness was further diminished following land cultivation. In southern Cameroon, experimental plots were disturbed by removing different combinations of epigeal termite mounds, surrounding litter, and soil to examine how termite community reassembly occurs following different degrees of disturbance. It was reported that communities reassembled quicker when significant dead wood was left on the ground (Davies et al. 1999). The vegetative history of the subdivision at the landscape-level may be an important predictor of future infestations due to nearby remnant woodlot patches and woody debris that potentially serve as sources of future subterranean termite colonizers.

Although treatment proportions were associated with dominant historical vegetation for the overall subdivision, treatments did not seem to be influenced by the historical vegetation of individual home lots. Twenty-year-old homes had a higher treatment proportion than 10-year-old homes, regardless of historical vegetation on individual lots. This demonstrates the importance of home age as a predictor of treatment proportion. However, there was no difference in treatment proportion between individual lots of the same age that were previously forested or agricultural. Pre-construction soil grading has been shown to directly remove ants from areas of soil disturbance (Buczkowski \& Richmond, 2012), and there is correlative evidence that subterranean termites 
are similarly removed from areas of disturbance (Botch \& Houseman, 2016). Vegetation and top soil is also removed or highly altered by grading (Capachi, 1978; Petschek, 2008), which may reset soil ecological conditions. Thus, the vegetative history of individual lots may not be an important predictor of future subterranean termite infestations because soil environmental conditions have been so heavily altered.

We predicted that treated homes would be found in relative close proximity to forest patches that potentially serve as colonization sources; however, there was less statistical support for this prediction than we expected. A greater sample size of treated homes may have helped us to better understand this relationship, as adjacency to forest patches was found to be an important predictor of treatment proportion in another study in Missouri (Houseman, 2010). In both 10- and 20-yearold historically agricultural subdivisions, treated homes were on average closer to forest patches than untreated homes. This is expected if subterranean termites colonize from forest patches via tunneling activity or dispersal flights. Interestingly, 10 -year-old historically forested subdivisions showed a more ambiguous pattern, where treated homes were on average farther away from forest patches at year 10, but not at year 20. These subdivisions had the lowest forest patch isolation (ENN value) and the greatest proportion of forested area near homes. Since densities of mature termite colonies can be very high in large forested areas (Vargo \& Husseneder, 2009), this may increase the likelihood of swarming termites dispersing further into subdivisions than they would by tunneling. Consequently, they might infest homes at greater distances, which would complicate our ability to predict infestations based on proximity to forest patches.

Spatial patterns and rates of subterranean termite colonization are likely to be species-specific, which we were not able to differentiate in this termiticide treatment survey. In a companion study to this survey, where wooden stake monitors were used to monitor homes not been previously treated for subterranean termites, we found that Reticulitermes flavipes (Kollar) was overwhelmingly the most common species found near homes (Botch \& Houseman, 2016). $R$. flavipes is the most widely distributed subterranean termite in North America (Snyder, 1954) and has often been reported to be the most common colonizer of urban areas (Austin et al., 2004a; Austin et al., 2004b; Wang et al., 2009; Vargo, 2003a; Parman \& Vargo, 2008; Pinzon \& Houseman, 2009). In our companion study, the subterranean termite species Reticulitermes hageni Banks was found in subdivisions less often, and tended to be located at the back of property lines, near or within woodlots (Botch \& Houseman, 2016). Studies have reported that $R$. hageni is also associated with forested areas in Oklahoma (Austin et al., 2004a; Brown et al., 2004). Thus, it is likely that most of the homes in this survey were treated for $R$. flavipes infestations, and $R$. hageni infestations are more likely to have occurred in subdivisions containing large patches of undeveloped forest.
Breeding structure in undeveloped forested areas was consistent with extended families in $60 \%$ of the colonies sampled (6 of 10). There was a 50:50 ratio of simple and extended families in both 10- and 20-year-old subdivisions. Therefore, a slightly higher proportion of extended families were found in forested landscapes than in urban subdivisions, potentially due to absence of anthropogenic disturbances. The overall inbreeding coefficient of individuals relative to the entire population $\left(F_{I T}\right)$ was highest in forested areas, so it can be inferred that termites in forested areas are more inbred overall than termites in urban subdivisions. Extended families had an $F_{I C}$ value close to zero, which is expected when secondary reproductives are present (Thorne et al., 1999; Vargo, 2003 b). $F_{I C}$ values in 10- and 20-year-old subdivisions were all strongly negative however, suggesting that these colonies contain few supplementary reproductives. It is possible that some colonies in residential subdivisions may have been misidentified as extended families due to low allelic diversity at two loci. This is supported by the fact that few colonies in 10- and 20-year-old subdivisions contained more than four genotypes at a given loci, compared to forested landscapes where $40 \%$ of the colonies contained five or more genotypes among one to three loci. DeHeer et al. (2005) concluded that 20 worker termites may not provide enough statistical power for distinguishing between simple and extended families when allelic variation is extremely low at any one locus. In this study, the loci $R s 18$ and $R s 85$ contained only two alleles among all colonies. In particular, $R s 85$ was only polymorphic in colonies from forested areas, and there was no variability in urban areas. Thus, it is possible that subdivisions contained a greater proportion of simple families than we were able to report genotyping only 20 workers per colony. However, inbreeding coefficients indicated that termite colonies in subdivisions had fewer supplementary reproductives, and thus were likely more recently established than colonies in forests.

Presumably, undisturbed forests provide an abundance of available food resources and favorable conditions for longterm colony growth and maturity, which may eventually lead to supplementary reproductives, increased fecundity, and inbreeding among colony members (Thorne et al., 1999). We found high levels of inbreeding in $R$. flavipes colonies collected in forests that supports this. DeHeer et al. (2005) reported populations of $R$. grassei in young forests contained relatively few supplementary reproductives and noted that there may be a correlation between colony age and forest age, because older forests contain more woody debris.In addition to resource availability, colony structure may also be affected by disturbance frequency. Aluko and Husseneder (2007) reported that extended families of Coptotermes formosanus replaced simple families in a frequently disturbed urban area in New Orleans over time and noted a transition of one colony from a simple to extended family. It is not clear whether low levels of inbreeding found in colonies we sampled in subdivisions was associated with human disturbance or new colonization 
events; however, it seems likely that an overall increase in treatment applications over time would likely suppress colony transition from simple to extended by killing colonies before they can produce supplementary reproductives.

This study may also provide evidence of the role of swarming into subdivisions. In 10-year-old historically agricultural subdivisions, treated homes were often found at distances exceeding $50 \mathrm{~m}$ from forest patches. This exceeds typical subterranean linear foraging distances for Reticulitermes spp. (Vargo \& Husseneder, 2009). When mature subterranean termite colonies swarm from adjacent large forest patches into subdivisions, they can presumably infest homes that are further away sooner than colonies that colonize via tunneling. If home infestations in 10-year-old historically agricultural subdivisions did not result from movement of wood and timber, then it is likely that termites colonized homes by dispersal flights rather than tunneling. Future studies of swarming patterns in subdivisions would provide important information about colonization dynamics and subsequent home infestation by subterranean termites.

\section{Acknowledgements}

We thank Deborah Finke, Bruce Barrett, and Mark Cowell for feedback and advice with this project. Thank you to Lori Eggert and Emily Puckett for valuable help with molecular assays. Support was provided by the National Institute of Food and Agriculture, U.S. Department of Agriculture-Hatch Project and the University of Missouri Research Council.

\section{References}

Aluko, G.A., \& Husseneder, C. (2007). Colony dynamics of the Formosan subterranean termite in a frequently disturbed urban landscape. Journal of Economic Entomology, 100: 1037-1046. doi: 10.1603/0022-0493(2007)100[1037:CDOTFS]2.0.CO;2

Austin, J.W., Szalanski, A.L. \& Kard, B.M. (2004a). Distribution and genetic variation of Reticulitermes (Isoptera: Rhinotermitidae) in Oklahoma. Florida Entomologist, 87: 152-158. doi: 10.1653/0015-4040(2004) 087[0152:DAGVOR]2.0.CO;2

Austin, J.W., Szalanski, A.L. \& Messenger, M.T. (2004b). Mitochondrial DNA variation and distribution of the subterranean termite genus Reticulitermes (Isoptera: Rhinotermitidae) in Arkansas and Louisiana. Florida Entomologist, 87: 473-480. doi: 10.1653/0015-4040(2004)087[0473:MDVADO]2.0.CO;2

Botch, P.S. \& Houseman, R.M. (2016). Landscape patterns of colonization by subterranean termites (Isoptera: Rhinotermitidae) in Missouri neighborhoods. Journal of Economic Entomology, 109: 800-808. doi: 10.1093/jee/tow010

Brown, K.S., Kard, B.M. \& Doss, M.P. (2004). 2002
Oklahoma termite survey (Isoptera). Journal of the Kansas Entomological Society, 77: 1-9. doi: 10.2317/0303-31.1

Buczkowski, G., \& Richmond, D.S. (2012). The effect of urbanization on ant abundance and diversity: A temporal examination of factors affecting biodiversity. PLoS One, 7: 1-9. doi:10.1371/journal.pone.0041729

Bulmer, M.S., Adams, E.S., \& Traniello, J.F.A. (2001). Variation in colony structure in the subterranean termite Reticulitermes flavipes. Behavioral Ecology and Sociobiology, 49: 236-243. doi: 10.1007/s002650000304

Capachi, N. (1978). Excavation and Grading Handbook. Craftsman Book Company. Solana Beach, CA. 320 p.

Davies, R.G., Eggleton, P., Dibog, L., Lawton, J.H., Bignell, D.E., Brauman, A., Hartmann, C., Nunes, L., Holt, J., \& Rouland, C. 1999. Successional response of a tropical forest termite assemblage to experimental habitat perturbation. Journal of Applied Ecology, 36: 946-962. doi: 10.1046/j.13652664.1999.00450.x

DeHeer, C.J. \& Vargo, E.L. (2004). Colony genetic organization and colony fusion in the termite Reticulitermes flavipes as revealed by foraging patterns over time and space. Molecular Ecology, 13(2): 431-441. doi: 10.1046/j.1365294X.2003.02065.X

DeHeer, C.J., Kutnik, M., Vargo, E.L., \& Bagneres, A.-G. (2005). The breeding system and population structure of the termite Reticulitermes grassei in Southwestern France. Heredity, 95: 408-415. doi:10.1038/sj.hdy.6800744

Dronnet, S., Bangeres, A.-G., Juba, T., \& Vargo, E.L. (2004). Polymorphic microsatellite loci in the European subterranean termite, Reticulitermes santonensis Feytaud. Molecular Ecology Notes, 4: 127-129. doi: 10.1111/j.14718286.2004.00600.x

ESRI (Environmental Systems Resource Institute). (2010). ArcMap 10.0. ESRI, Redlands, California.

Freeland, J.R. (2005). Molecular Ecology. John Wiley \& Sons, Ltd. West Sussex, England. 388 p.

Goudet, J. (2002). Fstat v 2.9.3.2. Institute of Ecology, UNIL, Lausanne, Switzerland.

Houseman, R.M. (2007). Wood-destroying pest management. Pesticide applicator training Category 7B. University of Missouri Extension. Columbia, MO.

Houseman, R.M. (2010). Predicting the likelihood of treatment for subterranean termites (Reticulitermes spp.) in Missouri neighborhoods, pp 99-103.In: S.C. Jones (eds.), Proceedings of the 2010 National Conference on Urban Entomology, 1619 May 2010, 2010. Portland, OR.

Lomolino, M.V., Riddle, B.R., \& Brown, J.H. (2006). Biogeography. 3rd Ed. Sinauer Associates, Inc., Sunderland, Massachusetts, $845 \mathrm{p}$. 
Matsuura, K., Himuro, C., Yokoi, T., Yamamoto, Y., Vargo, E.L., \& Keller, L. (2010). Identification of a pheromone regulating caste differentiation in termites. Proceedings of the National Academy of Sciences, 107: 12963-12968. doi: 10.1073/pnas.1004675107

McDonnell, M.J. \& Pickett, S.T.A. (1990). Ecosystem structure and function along urban-rural gradients: An unexploited opportunity for ecology. Ecology, 71: 12321237. doi: $10.2307 / 1938259$

McGarigal, K., Cushman, S.A., Neel, M.C., \& Ene, E. (2002). FRAGSTATS v3: Spatial Pattern Analysis Program for Categorical Maps. Computer software program produced by the authors at the University of Massachusetts, Amherst. Available at the following web site: http://www.umass.edu/ landeco/research/fragstats/fragstats.html

McIntyre, N.E. (2000). Ecology of urban arthropods: a review and a call to action. Annals of the Entomological Society of America. 93: 825-835. doi: 10.1603/0013-8746 (2000)093[0825:EOUAAR]2.0.CO;2

Okwakol, M.J. 2000. Changes in termite (Isoptera) communities due to the clearance and cultivation of tropical forest in Uganda. African Journal of Ecology, 38: 1-7. doi: 10.1046/j.1365-2028.2000.00189.x

Parman, V. \& Vargo, E.L. (2008). Population density, species abundance, and breeding structure of subterranean termite colonies in and around infested houses in central North Carolina. Journal of Economic Entomology, 101: 1349-1359. doi: $10.1093 /$ jee/101.4.1349

Petschek, P. (2008). Grading for Landscape Architects and Architects. Birkhäuser Architecture. Berlin, Germany, 221 p.

Pinzon, O.P. \& Houseman, R.M. (2009). Species diversity and intraspecific genetic variation of Reticulitermes (Isoptera: Rhinotermitidae) subterranean termites in woodland and urban environments in Missouri. Annals of the Entomological Society of America, 102: 868-880. doi: 10.1603/008.102.0513

Rust, M.K. \& Su, N.-Y. (2012). Managing social insects of urban importance. Annual Review of Entomology, 57: 355375. doi: 10.1146/annurev-ento-120710-100634

SAS Institute Inc. (2011). SAS/STAT User's Guide, Version 9.3. Cary, NC.

Sattler, T., Obrist, M.K., Duelli, P, \& Moretti, M. (2011). Urban arthropod communities: Added value or just a blend of surrounding biodiversity? Landscape and Urban Planning, 103: 347-361. doi: 10.1016/j.landurbplan.2011.08.008

Snyder, T.E. (1954). Order Isoptera. The termites of the United States and Canada, National Pest Control Association, New York. 64 p.

Sokal, R.R. \& Rohlf, F.J. (2012). Biometry: the principles and practice of statistics in biological research. 4th edition. W.H.
Freeman and Co. New York. 937 p.

Su, N.-Y. \& Scheffrahn, R.H. (1990). Comparison of eleven soil termiticides against the Formosan subterranean termite and eastern subterranean termite (Isoptera: Rhinotermitidae). Journal of Economic Entomology, 83: 1918-1924. doi: 10. 1093/jee/83.5.1918

Su, N.-Y.\& Scheffrahn, R.H. (1998). A review of subterranean termite control practices and prospects for integrated management programs. Integrated Pest Management Review, 3: 1-13. doi: 10.1023/A:1009684821954

Szalanski, A.L., Austin, J.W., \& Owens, C.B. (2003). Identification of Reticulitermes spp. (Isoptera: Rhinotermitidae) from South Central United States by PCRRFLP. Journal of Economic Entomology, 96: 1514-1519. doi: 10.1603/0022-0493-96.5.1514

Thermo Fisher Scientific (2012). Peak Scanner 1.0. Thermo Fisher Scientific, Waltham, Massachusetts.

Thorne, B.L., Traniello, J.F.A., Adams E.S., \& Bulmer, M. (1999). Reproductive dynamics and colony structure of subterranean termites of the genus Reticulitermes (Isoptera Rhinotermitidae): a review of the evidence from behavioral, ecological, and genetic studies. Ethology Ecology \& Evolution, 11: 149-169. doi: 10.1080/08927014.1999.9522833

Traniello, J.F.A. \& Leuthold, R.H. (2000). Behavior and ecology of foraging in termites, pp. 141-168. In: T. Abe, D.E. Bignell, and M. Higashi (eds.), Termites: Evolution, Sociality, Symbioses, Ecology. Kluwer Academic Publishers, Netherlands, 466 p.

Turner, M.G., Gardner, R.H., \& O’Neill, R.V. (2001). Landscape Ecology. In Theory and Process. Springer-Verlag, New York, 406 p.

Vargo, E.L. (2000). Polymorphism at trinucleotide microsatellite loci in the subterranean termite Reticulitermes flavipes. Molecular Ecology, 9: 817-829. doi: 10.1046/j.1365294x.2000.00915.x

Vargo, E.L. (2003a). Genetic structure of Reticulitermes flavipes and $R$. virginicus (Isoptera: Rhinotermitidae) colonies in an urban habitat and tracking of colonies following treatment with hexaflumuron bait. Environmental Entomology. 32: 1271-1282. doi: 10.1603/0046-225X-32.5.1271

Vargo, E.L. (2003b). Hierarchical analysis of colony and population genetic structure of the eastern subterranean termite, Reticulitermes flavipes, using two classes of molecular markers. Evolution, 57: 2805-2818. doi: 10.1554/03-336

Vargo, E.L. \& Husseneder, C. (2009). Biology of subterranean termites: Insights from molecular studies of Reticulitermes and Coptotermes. Annual Reviewof Entomology, 54: 379403. doi: 10.1146/annurev.ento.54.110807.090443

Waller, D.A. \& La Fage, J.P. (1987). Nutritional ecology 
of termites, pp. 487-532 In: F. Slanksy and J.G. Rodriguez (eds.). Nutritional Ecology of Insects, Mites and Spiders. Wiley Interscience, New York, NY, 1016 p.

Wang, C., Zhou, X., Li, S., Schwinghammer, M., Scharf, M.E., Buczkowski, G., \&Bennett, G.W. (2009). Survey and identification of termites (Isoptera: Rhinotermitidae) in Indiana. Annals of the Entomological Society of America, 102: 10291036. doi: 10.1603/008.102.0611
Weesner, F.M. (1965). The Termites of the United States. A Handbook. The National Pest Control Association. New Jersey, USA, 67 p.

Weir, B.S. \& Cockerham, C.C. (1984). Estimating F-statistics for the analysis of population structure. Evolution, 38: 13581370. doi: $10.2307 / 2408641$ 